\title{
Causes of Voluntary Dropout of Microfinance Clients in Bangladesh
}

Prof. Muhammad Ziaulhaq Mamun, $P h D^{1}$

\begin{abstract}
The study of the causes of the MFI clients' drop-outs conducted through a survey on 30 dropped out clients with the help of structured questionnaire revealed that there are not too many strong reasons for dropout. The clients and their family and relatives are found quite happy with the MFI loan amount, interest rate, and peer guarantee system.

The responses show that clients disinterest to take another loan is the most important cause of dropout. Other significant causes of dropouts are linked with stringent product features, especially the loan repayment procedures, which include no need for another loan, non-negotiable installment size, short repayment intervals, limited grace period, high interest rate, personal solvency, high savings rate, and strict overdue payment policy. On the other hand the least important causes of dropouts are non-beneficial savings scheme, more expensive than traditional money lenders, family or relatives' disapproval, inflexible loan amount to business requirements, more expensive than other MFIs, the peer guarantee system, narrow range of loan packages.
\end{abstract}

Key Words: Loan Repayment, Microfinance, Microfinance Institutions, Non-negotiable Installment, Solvency

\section{Introduction}

\subsection{Issue}

Microfinance ${ }^{1}$ has started in Bangladesh in 1976 as solidarity groups guarantee system for the members of the impoverished socio-economic background people. A rapid growth in the microfinance sector was experienced in the mid 1980s when both clients and microfinance institutions (MFI) ${ }^{2}$ started entering the sector. By a decade, around $90 \%$ of the poor population of Bangladesh was directly or indirectly came under MFIs purview. Now, microfinance is considered one of the most effective tools for poverty reduction

1 Institute of Business Administration, University of Dhaka, Bangladesh, Email : mzmamun@iba-du. edu,mzmamun@yahoo.com 
(Khandker et al. 2010). A longitudinal study (2000 to 2010) noted that microfinance accounts for $9 \%$ of the poverty reduction in Bangladesh (Khandker \& Samad, 2013). Currently, around $29 \%$ of the population lives under poverty which is a significant decrease from 56\% in the beginning of the millennium (GDE, 2013). However, a large population is still not positively affected by microfinance. In addition, in recent years, the growth of micro-finance has been decreasing significantly. A significant cause of this decrease in growth is the dropout ${ }^{3}$ phenomenon among MFI members. This trend affects not only the profitability and future sustainability of the MFIs, but also the dropped out clients who may have benefited from continued participation with the MFI (Pearlman, 2014).

Irregular participation or complete disengagement of a client from microfinance reduces the possibility of graduation from poverty. Clients who participate on a long-term basis (around 20 years) are more likely to be better off in terms of standard of living (Khandker \& Samad, 2013). Length of enrollment period is positively associated with accumulation of household assets which directly correlates with household well being (Barua \& Sulaiman, 2007). From an organizational perspective, client retention is a desirable phenomenon as it reduces program inefficiency and ensures stability (Majumder, 2009; Rani, 2012). Various studies have shown that long-term participation is beneficial for both the client and the microfinance institution alike. Despite the positive effects of availing microcredit $^{4}$ services, members are dropping out from MFIs at a considerably rate. BRAC, one of the largest NGO (Non-Government Organization) in Bangladesh, reported a dropout of $15 \%$ per year in 2007, while Sajida foundation, a much smaller MFI, reported member discontinuation of $53 \%$ in 2008.

As competition or potential competition from mainstream, formal-sector banks appears to steer microfinance institutions toward serving poorer customers, the commercial banks are interested in serving the well to do people, while MFIs have only the lower income people to serve. Despite the fact that MFIs are serving poor households, a substantial share of "non-profits" in fact earns profits, even if they are relatively small (Cull, Demirguc-Kunt, \& Morduch 2009). However, most institutions serving the poorest customers earn profits too small to attract investors seeking purely commercial returns (rather than a blend of "social" and financial returns). Hence financial self-sustainability and serving poor households are not, by definition, incompatible. This illustrates the sheer reality of doing business in Bangladesh for the MFIs.

Bangladesh microfinance sector is considered as one of the largest and most efficient in the world (Zaman, 2013). One of the major achievements of the leading MFIs is high recovery rate (97.0\% - 99.84\%). Among of the major problems faced by these MFIs are overlapping in multiple borrowing, lack of reliable database, lack of trained work force, insufficient repayment time, etc. Gathering information about dropout clients relates both to the performance of the MFI in relation to client needs, and more generally to how 
an MFI relates to client livelihoods and external conditions which can form a core part of impact understanding (Simanowitz, 2000). Thus, understanding feeds into operational development and leads to changes that better tailor the MFI's services to their target client needs and thus improves the overall impact of the MFIs.

Voluntary member discontinuation or dropout is a concern for all stakeholders involved in the microfinance sector. It is detrimental to not only the clients and the MFIs, but to the overall economic development of the country. The research focused on studying the causes of voluntary client dropout - not expulsions, or involuntary dropout from the MFIs which is a result of failure of loan repayment (defaulting ${ }^{5}$ ), behavioral misconduct and/ or other problematic factors.

Specifically, the study on causes of MFI member dropouts looked into the following objectives:

i. To examine the microfinance organizational procedures

ii. To study the problems faced by clients

iii. To find out the reasons behind client dropouts and

iv. To suggest means to reduce this adverse phenomenon

\section{Literature Review}

\subsection{Product Characteristics}

The age old primary cause of client dropouts lies in the fact that organizations go for a product-driven, rather than market-driven approach when it comes to dealing with customers (Wright 1997). More specifically, inappropriately designed loans, poorly designed savings and failure to customize products, lead to client dropouts. Hence MFIs who are willing to develop a sustainable financial institution must make improvements in their services. However, it is to be noted, that MFIs in Bangladesh are now increasingly aware of their customer needs and go a long way to maintain sustainable client relations. They offer various kinds of loans including seasonal loans that come with zero interest. Nevertheless, the savings or deposit services in the MFIs are still rigid and inconvenient for clients (Rahman 2006, Hossain 2003). Many even do not know about the product rules and the MFI personnel intentionally do not update the clients regarding these issues.

As noted by Quayes and Khalily (2013) old and big MFIs are more efficient because of their large size making them operationally more efficient. Larger MFIs, thus, do not require charging a higher interest rate - an important factor of client dissatisfaction and ultimate dropout. Furthermore, as noted by Wright (1997), MFIs used to be very standardized, inflexible and credit driven making the loan less attractive. However, in recent times, it is observed that the efficiency of the MFIs is increasing. MFIs are reported to have psycho- 
social programs whose primary aim is to provide psychological counseling to both the clients and the loan officers so that more efficient microcredit services can be provided and reduce the frequent resentment that would occur between the parties involved in the weekly installment dealings. For these reasons and more, most of the dropped out clients surveyed, reported that the organizational reasons were not a major cause of dropping out.

Interest rate of MFIs is a much talked about issue. It is claimed that MFIs keep too high interest rates and are very business oriented. However, interest rate of MFIs are below cost recovery levels (Pagura, 2003), if anything. The reason for the presumably high interest rate (as high as $27 \%$ ) placed on micro loans, is that it is calculated on a declining method ${ }^{6}$ and opposed to flat method. The latter method accounts for the interest calculation in commercial banks. The catch is that an interest rate of $30 \%$ in the declining method is equivalent to a $15 \%$ interest rate in flat method. All MFIs, under Microfinance Regulatory Authority's rules, are bound to charge interest rate of maximum $27 \%$ at declining balance method (Khalily et al. 2014). It is prohibited to deduct from principle loan amounts, and this gives the customers to pay interest only on the loan they currently have after having paid the installments and not the loan they initially took.

\subsection{Multiple Borrowings}

Other organizational reasons like larger loan need, overlapping/alternative loans, no benefit from loan and other factors, play a major role in deciding whether clients will dropout. Among these reasons, multiple borrowing is a phenomenon of rising concern in the society (Rahman, 2006). Even though this cause is not high at the importance scale, it is a common phenomenon now days. Client's requirement for larger loans, insufficient product range in any one MFI, client's need for consumption or crisis loans, complicated interest rates and inflexible repayment in any MFI, all lead to multiple borrowing. Multiple borrowing or overlapping loans by borrowers is a misuse of credit $^{7}$ leads to rising mental stress for not being able to pay the multiple loans, delinquency and defaults, leading to dropouts. Rate of multiple borrowing in Bangladesh is between 40 to $60 \%$ and the growth has been reported to be around 15\% (Khalily \& Faruqee, 2011).

Many clients take loans from local money-lenders popularly known as mohajons ${ }^{8}$ at extremely high interest rates and lose all their properties. These "loan sharks" are believed to have influence over their area of interest. Because of this mixed loan taking many clients cannot actually realize separately the benefits of micro-credit. They blame their misery both on mohajons and micro-credit. Clients who take multiple loans have to pay multiple lenders at a time. This overburdens the client and makes him/her mentally stressed out. Even after recovering from this financially feeble state, many clients dropout as they are left with a more negative perception towards any loans.

$22 \sim$ Nepalese Journal of Insurance and Social Security 
Information gaps between MFIs leads to this phenomenon of multiple borrowing. Steps by the Microfinance Regulatory Authority would ensure that MFI's selection process is more coordinated through an integrated extranet and instances of multiple borrowing are at a minimum. However, in some cases, it is impossible to identify multiple borrowers as clients may use different spellings or ID cards. Furthermore, MFIs often do not see multiple borrowing as a cause of concern as long as the client is able to pay the weekly instalments.

\subsection{Client Dissatisfaction}

A number of studies (Barua and Sulaiman, 2007; Rahman, 2006) found that microfinance client dissatisfaction is positively associated with dropout. According to these studies high interest rates, inflexibility in savings withdrawal and inflexibility in repayment are some major areas of client dissatisfaction. The study also concluded that poorer clients are more likely to dropout and that incidence of life cycle events (like marriage, retirement, education enrollment, etc), homogeneity of group members and having alternative services have chances of dropping out.

Some reasons for dissatisfaction of clients include the savings and borrowing procedure (Inez, 2001). The clients are not even aware of product rules. The credit staffs deliberately do not apprise and update the clients. Mostly withdrawal is not allowed from the savings account (79\% of the cases). Furthermore, most of the people (72\%) are not satisfied with current disbursable loan size. The given loans hardly meet their needs. Consequently, they have to shop around for the additional money from other sources as they cannot do any business or productive work meaningfully with small loans (Rahman, 2006). The study concluded that clients are not happy with current provisions of loans and think that it should increase at least by $50 \%$ than what they are getting now. Furthermore, clients demand an increase on the interest rate on savings which is generally $5 \%$.

Hossain (2003) discusses the causes of dropout from various perspectives like - membership process, savings, credit management, etc. His study explored the microfinance dropout and identified the socioeconomic or health crisis from dropout. Other variables included MFI's management problem, overlapping of members, lack of training and dropout among other.

\subsection{Competition leading to Better Services}

Rahman (2006) found an effect of competition among the MFIs on interest rates. The average interest rate charged by the MFIs ranges from $12-15 \%$ with Grameen Bank charging the lowest (10\%). Clients seem to be satisfied with this aspect of the MFIs. Furthermore, MFIs make themselves seem like a more lucrative option by providing complementary social services that includes health, children \& adult education, sanitation $\&$ hygiene, etc. To attract the clients they also hold group meetings with social leaders and explain their products and services and the accompanying benefits. 


\subsection{Solvency}

Majumder's (2009) study found that $82 \%$ of the dropped out clients left voluntarily. In his study, it was concluded that $37 \%$ left the MFI because they did not need any loan. Indeed, $65 \%$ of the dropped out clients were running their businesses well even after dropping out. However, even if clients graduate from their poor state, member discontinuation is undesirable in the sense that graduates are more affluent and self-confident (Wright, 2000). The graduates who still avail the micro credit services usually take larger loans which benefit the MFIs by expanding their working capital. MFIs, as a result, are able to experience higher profit since cost of administering these loans is same regardless of size. Furthermore, graduates, or larger clients, help to finance smaller loans to poorer clients. Hence, retaining clients, especially if the client is running a sustainable business, is of quintessential importance for MFIs.

\subsection{Reasons for Concern}

Pagura (2003) study on MFI client dropouts revealed the fact that long-term relationship with MFI and clients are beneficial to both parties is the reason why high dropout rate is a matter of concern. As the relationship matures the lender benefits from lower screening and monitoring costs, increased revenue and improved lending decisions given that risk decreases as more information about the borrower is revealed. Clients benefit from a continued and often expanded access to credit. This is because of the cost reduction in capital as terms and conditions improve over the long run, and an opportunity to establish a valuable reputation as a trustworthy borrower is created. The study identified poor loan products and services, inaccessibility and low interest on savings, the frequency and length of group meetings, the small loan amounts topped with high interest rates, and negligence of staff, overall poor quality service of MFIs, idiosyncratic, and other market driven factors as primary causes of client dropouts.

Pagura's (2003) claim is more reinforced by Khandker and Samad (2013). In their longitudinal study to find out the microfinance growth and poverty reduction in Bangladesh, it was found that clients who participate over the 20 year period since 1991/1992 have consistently done much better than those who have participated in an irregular fashion or on short-term basis. They concluded that poverty reduction impact for continuous participation is higher than it is for participation in general. According to the study, microcredit intervention accounts for over $9 \%$ of the total poverty reduction in rural Bangladesh in the ten years of program intervention (from 2000 to 2010).

\section{Methodology}

The study made use of both primary and secondary data and pertinent literature review. Primary data were collected by means of questionnaire survey. A non-probabilistic convenience sampling technique was followed to get the responses of the drop-outs. The study surveyed 30 dropped-out clients from three types of MFIs: 1) Big (4), 2) Medium 
(15) and 3) Small (11). Of these 30 respondents, the mean age was 38.37 years (st. dev. 14.09 years). Of all the respondents 26 were female housewives and the rest 4 were male. All the respondents were married. The mean monthly income found to be \$ 325 (st. dev. \$ 552). Most respondents had household members of around 4.4 (st. dev. 1.83).

Clients surveyed (30) from these three MFIs may not be true and proportionate representation of the whole dropout client population in Bangladesh. But considering inconvenience and inaccessibility of the dropout clients this study of this 30 clients can be very informative and a way forward. Descriptive statistics (Index number, Mean, Standard deviations, t-test, etc.) is mainly used for data analysis. A 5-point Likert scale (1: least important, 5: Most important) is used to find out causes of clients dropout. Extensive literature review greatly helped in understanding the dynamics of member dropouts. This is supported by a few MFI executives interview regarding their products, conduct with clients, causes of dropouts, retention strategies, etc. Secondary data was the primary basis of pinpointing the possible variables of client dropouts. The variables gathered from relevant literature were used to construct the schema (Appendix 1) and questionnaire.

\section{Result and Discussion}

The study on causes of dropout of the MFI clients are divided into 3 broad categories: Organizational (Product features), Clientele (Peer/Group/Cooperative) and environmental (Personal/Family). Each of these categories has 16, 15, and 10 simple variables respectively. All these simple variables (41) were carefully chosen from previously done researches, literature review, expert opinion, etc., following the face validity ${ }^{9}$. Respondents were asked to rank these 41 reasons behind dropping out in a scale of 1 to 5 ( $1 \rightarrow$ least important, $5 \rightarrow$ most important). A Cronbach's Alpha of 0.715 (> 0.70 ) indicates that the responses are reliable.

As noted the mean indices of the responses lie mostly between 1 and 2 (Appendix 2). This indicates that there are not too many strong reasons for dropout. The top few causes of dropouts are no need for another loan (3.17), non-negotiable installment size (2.53), short repayment intervals (2.40), limited grace period (1.97), high interest rate (1.93), personal solvency (1.93), high savings rate (1.67), and strict overdue payment policy (1.64). It appears that most of the common causes of dropouts are linked with solvency and stringent product features. On the other hand the least important causes of dropouts are nonbeneficial savings scheme (1.07), more expensive than traditional money lenders (1.07), family or relatives disapproval (1.13), inflexible loan amount to business requirements (1.13), more expensive than other MFIs (1.17), the peer guarantee system (1.17), narrow range of loan packages (1.17). The responses indicate that the clients are quite happy with the MFI loan amount and interest rate, peer guarantee system. Also the family and relatives seems to have no-complain against the loan. The study further analyzed category-wise causes of dropout perceived by the respondents are discussed below. 


\subsection{Organizational Reasons}

The organizational reasons of dropout are mainly concerned with product characteristics. The quality, efficiency and variety of services provided by MFIs play a great role in client dropouts. It is of fundamental importance for organizations to continuously come up with customer-driven loan products (Wright 2000) rather than product driven approach to reduce member dropouts. Clients feel dissatisfied with inappropriately designed loans which do not meet their needs. Here 15 causes of dropouts are identified which includes loan procedure, repayment procedure, and savings related issues (Table 1). Overall the respondents noted that none of the loan features were a major reason for dropping out, but there is variation among the responses. The mean $(\mu)$ indices of the ratings are found between 1.07 and 2.53 .

Table 1: Organizational (Product features) Causes of Dropout

\begin{tabular}{lll}
\hline Broad Groups & Simple Variables \\
\hline 1. Loan procedure & 1) & Increment in loan size was inadequate (1.50) \\
& 2) & Waiting time to receive loan was very long (1.47) \\
& 3) & Loan application fee was excessive (1.40) \\
& 4) & Loan application system was not user-friendly (1.37) \\
& 5) & Range of loan packages was narrow (1.17) \\
\hline 2. Rigid instalment & 6) & Instalment size was not negotiable (2.53) \\
& 7) & Repayment intervals were short (2.40) \\
& 8) & There was no grace period (1.97) \\
& 9) & Interest rate was high (1.93) \\
& 10) & The system of paying overdue was strict (1.64) \\
\hline 3. Savings related & 11) Savings requirement for borrowing was high (1.67) \\
issues & 12) There was no interest on voluntary savings (1.37) \\
& 13) & Terms of savings withdrawal was inflexible (1.33) \\
& 14) & Rate of voluntary savings was high (1.30) \\
15) & The savings scheme of the MFI was not beneficial (1.07) \\
\hline
\end{tabular}

All the reasons linked in the loan procedure [inadequate increment in loan (1.50), waiting time (1.47), loan application fee (1.40), unfriendly loan application system (1.37), Narrow range of loan packages (1.17)] have low mean values indicating the fact that there is little dissatisfaction in the loan process and they are not a major cause of dropout. While the overall loan features were not a key reason for dropping out, the loan repayment procedures proved to be a moderately important reason for dropping out. These include rigid instalment size (2.53), short repayment intervals (2.40), no grace period (1.97), high interest rate (1.93), and strict overdue payment system (1.64). Hence, inflexibility in instalment size acted as a moderately important reason for client dropouts.

$26 \sim$ Nepalese Journal of Insurance and Social Security 
Savings related issues are found to be not so strong reason for dropouts. The savings related factors like high savings requirement (1.67), no interest on voluntary savings ${ }^{10}$ (1.37), inflexible terms of savings withdrawal (1.33), high rate of voluntary savings (1.30), non beneficial savings schemes (1.07) are found to be least notable reasons of dropping out. The key reason for this, as reported by the MFI officials, is that females (who make up 90\% of the client base) are usually willing to save even if it is just a meager amount ( $\$ 0.12$ per week) for the future benefit of their family members. Most MFIs have inflexible savings procedure (Rahman, 2006). The compulsory savings requirement for loan is also hard for members to meet. Even if the interest rate placed on savings is very low (5\% - 8\%), has influenced some respondents to discontinue their membership (As they perceive this rate to be high).

\subsection{Clientele Reasons behind Client Dropouts}

The clientele reasons of MFI dropout include cooperative/group related activities, e.g., group loan ${ }^{11}$, group cohesiveness, MFI service to the group. Here 16 variables were identified (Table 2). Overall response of the clients in this area is not found to be very negative and not major causes of dropout ( $\mu=1.43 \sim 1.07)$. The respondents of different clusters also do not differ that much on their group satisfaction level, as suggested by the low standard deviation. Two notable causes are availability of alternate loans (1.43) and rare inspection of the MFI officials visit to the business (1.40).

Table 2: Clientele (Peer) Causes of Dropout

\begin{tabular}{lll}
\hline Broad Groups & & \multicolumn{1}{c}{ Variables } \\
\hline 1. Group-based & 1) & Alternative loans were available at that time (1.43) \\
lending & 2) & Maximum loan size was inadequate (1.33) \\
& 3) & The business was not making profit (1.30) \\
& 4) & The interest amount paid to the MFI was higher than the profit I \\
& make (1.23) \\
& 5) & The loan from MFI is more expensive than other MFIs (1.17) \\
& 6) & The loan amount does not vary according to my business \\
& 7) & The MFI loan is more expensive than traditional money lenders (1.07) \\
\hline 2. Group & 8) & The group meetings were long (1.37) \\
cohesiveness & 9) My group members were unfriendly (1.20) \\
& 10) I disliked the peer guarantee system (1.17) \\
& 11) The MFI is located very far from my workplace (1.27) \\
& 12) The MFI is located very far from my residence (1.20) \\
\hline 3. MFI service & 13) The loan officers rarely come to inspect my business (1.40) \\
to groups & 14) Officers were not open to suggestions (1.30) \\
& 15) The MFI officials do not provide any advice on how to run my \\
& 16) Lusiness (1.23)
\end{tabular}


Regarding group-based lending the study noted that availability of alternate loans (1.43), inadequate maximum loan size (1.33), not so profitable business (1.30), higher interest amount than the business profit (1.23), more expensive loan than other MFIs (1.17), fixed loan amount for varying businesses (1.13), MFI loan is more expensive than traditional money lenders (1.07) are minor reasons for MFI dropout.

Regarding group cohesiveness the frequency and length of group meetings (1.37) along with relation with the fellow group members (1.20) and peer guarantee (1.17) found to have minimal affect on clients' satisfaction that may lead to dropout. In this regard the respondents did not show much dissatisfaction regarding the accessibility and convenience of the MFI location from their work place (1.27) or residence (1.20). It has been found in several studies that majority of respondents across regions do not like peer guarantee system. The new members have to take a disproportionate risk and guarantee the larger sums taken by their fellow group members, adding further stress to the group guarantee. Not only do they dislike paying for others, but also they do not like others paying for them, (Inez, 2001, Wright 1997).

Regarding MFI service to the group the responses were not very negative. The respondents did not strongly agree that the loan officers rarely come to inspect the business (1.40), not open to suggestions (1.30), do not provide any advice on how to run my business (1.23), and do not behave professionally (1.20). Due to various factors, including clients not understanding the risks of borrowing and loan officers' impatience under stress can generate bad interaction/harsh behavior with clients and ultimate discontinuation (CHIP 2002). The frequency of inspection by loan officers and training facilities of the related organizations also affects the perception of the clients regarding the MFI service and can lead to discontinuation. The psycho-social program of MFIs help field officers and clients to deal with stress is showing positive results and is helping in building longterm relationships.

\subsection{Environmental Reasons behind Client Dropouts}

Environmental Reasons behind Client dropouts mainly considers family or personal reasons that can cause a member dropout from an MFI. In this category 10 variables were identified in 3 sub-groups: 1) Personal solvency, 2) Personal loan related issues, 3) Miscellaneous. (Table 3). Overall response in this area is found to be moderate causes of dropout ( $\mu=1.13 \sim 3.17$ ). The respondents of different clusters also do not differ that much on their group satisfaction level, as suggested by the low standard deviation. The responses show that clients disinterest to take another loan (3.17) is the most important cause of dropout followed by clients' solvency (1.93), and employment opportunity or leading a profitable micro enterprise (1.57).

It is important to note, that most of the dropped outclients surveyed, were at a considerably affluent state at the time. This shows, that major reason for dropping out is not related to 
the organization but to the fact that clients become most independent as their business starts to give profits and no longer need any loan. This phenomenon of clients graduating and then dropping out is not surprising, given the fact that microfinance has been playing its role in Bangladesh for over 40 years. It is time that MFIs bring about a shift in gear to meet the needs of a more affluent customer base alongside poorer ones. However, MFIs must not lose their micro perspective as there are already banks providing small medium enterprise (SME) loans to less deprived clients.

Table 3: Environmental (Personal/Family) Causes of Drop-out

\begin{tabular}{lll}
\hline Broad Groups & \multicolumn{2}{l}{ Simple Variables } \\
\hline 1. Personal solvency & 1) & I was not interested to take another loan at that time (3.17) \\
& 2) & I became solvent enough (1.93) \\
& 3) & I found employment/or leading a profitable micro enterprise \\
& & (1.57) \\
\hline $\begin{array}{ll}\text { 2. Personal loan } \\
\text { related issues }\end{array}$ & 4) & I needed a loan larger than what my MFI could provide (1.57) \\
& 5) & I have not benefited from the microfinance loan (1.27) \\
& 6) & I used the loaned money to meet household expenses (1.34) \\
& 7) & I became legally ineligible for loan (1.30) \\
\hline 3. Miscellaneous & 8) & I migrated to another location (1.47) \\
& 9) & Some unexpected events took place (death, illness, etc.) (1.47) \\
& 10) & My family or relatives were against the loan (1.13) \\
\hline
\end{tabular}

As already noted personal solvency is the main important reason for client dropout. Personal loan related less significant issues include: insufficient loan amount (1.57), misuse of loan to meet household expenses (1.34), loan ineligibility, (1.30), and nonbeneficial loan (1.27). Insufficient loan amount due to expansion of business to some extent found to be a cause of dropout. It was noted that prospective client often make factual distortion to MFIs and instead of investing in a presumable profitable business, they invest the loans on a risky business. Even other times, clients take loans to spend in non profitable events like daughter's marriage, dowry, house building etc. To address this problem, MFIs now introduced a special product called "consumption loans" which are meant for expenditure rather than business. Such loans are disbursed with special care by MFIs as clients who do not have regular income will be unable to repay the loan, and become defaulters. Too much coercion for repaying poorly handled consumption loans, may lead to permanent dropouts. Loan eligibility refers to the legal competence of a person to take a loan from an organization. The compliancy criteria usually include age, previous loan record, financial condition etc., varying around the organizations.

Other least significant miscellaneous reasons include migration to another location (1.47), unexpected happening, e.g., death, illness, etc., (1.47), and family or relatives 
unwillingness (1.13). Contrary to our findings, it is evident from the previous researches that a significant number of members have dropped out due to such events. Nevertheless, migration plays an important role in member dropout. It is important to note that many clients, who have migrated from one area and consequently dropped out, often re-join the same MFI at the new location. In most cases health related problems are more acute that requires lots of money to treat and put barrier to their participation in income earning activities.

The minimal dropout due to family disapproval is in contradiction to Karim's (2005) study where he found that $20 \%$ of the females dropout for family problems. He perpetuated that because females have to leave household to attend group meetings, it is considered against cultural norms. However, in our study, none of the respondents said that family disapproved was a major cause of dropout. Hence, it can be said, that there has come about a cultural shift in norms, and husbands and other family members, are more comfortable with seeing their female members actively participate in income generating activities.

Contrary to this finding, it must be noted, that most of the female respondents who had taken loans, had done so as per their husband's decision and not their own. This is a worrying fact as most NGOs aim to disburse loans to the females because they are the key driver of socio-economic growth (Cull, Demirguc-Kunt, \& Morduch 2009). Hence, while the culture of not letting women be outgoing is slowly shifting, men are still in charge of taking decisions regarding availing credit services and its usage.

\section{Conclusions}

\subsection{Conclusions}

The study of the causes of the MFI clients' drop-outs is based on survey of 30 droppedout clients from different types of MFIs. The small may not be true and proportionate representation of the whole dropout client population in Bangladesh; but considering inconvenience and inaccessibility of the dropout clients this study is very informative and a way forward. Extensive literature review greatly helped in understanding the dynamics of member dropouts. This is supported by a few MFI executives interview regarding their products, conduct with clients, causes of dropouts, retention strategies, etc. Secondary data was the primary basis of pinpointing the possible variables of client dropouts.

The causes of dropout of the MFI clients are divided into 3 broad categories: Organizational, Clientele and environmental. The survey noted that there are not too many strong reasons for dropout. The top few causes of dropouts are no need for another loan, non-negotiable installment size, short repayment intervals, limited grace period, high interest rate, personal solvency, high savings rate, and strict overdue payment policy. It appears that most of the common causes of dropouts are linked with stringent product features. It also

$30 \sim$ Nepalese Journal of Insurance and Social Security 
appears that unless required the clients are not willing to take MFI loans. On the other hand the least important causes of dropouts are non-beneficial savings scheme, more expensive than traditional money lenders, family or relatives' disapproval, inflexible loan amount to business requirements, more expensive than other MFIs, the peer guarantee system, narrow range of loan packages. The responses indicate that the clients are quite happy with the MFI loan amount and interest rate, peer guarantee system. Also the family and relatives seems to have no-complain against the loan.

The organizational reasons of dropout are mainly concerned with product characteristics. This broadly includes loan procedure, repayment procedure, and savings related issues. Overall the respondents noted that none of the loan features were a major reason for dropping out, but there is variation among the responses. The reasons linked with the loan procedure (inadequate increment in loan, waiting time, loan application fee, unfriendly loan application system, Narrow range of loan packages) are not a major cause of dropout. The loan repayment procedures proved to be a moderately important reason for dropping out. These include rigid instalment size, short repayment intervals, no grace period, high interest rate, and strict overdue payment system. Savings related issues like high savings requirement, no interest on voluntary savings, inflexible terms of savings withdrawal, high rate of voluntary savings, non-beneficial savings schemes are found to be least notable reasons of dropping out. The key reason for this, as reported by the MFI officials, is that females are usually willing to save even if it is just a meagre amount for the future benefit of their family members.

The clientele reasons of MFI dropout are not found to be very negative and not major causes of dropout. Two notable causes are availability of alternate loans and rare inspection of the MFI officials visit to the business. Regarding group-based lending the study noted that availability of alternate loans, inadequate maximum loan size, not so profitable business, higher interest amount than the business profit, more expensive loan than other MFIs, fixed loan amount for varying businesses, MFI loan is more expensive than traditional money lenders are minor reasons for MFI dropout. Group cohesiveness (e.g., frequency and length of group meetings, relation with the fellow group members and peer guarantee) found to have minimal impact on clients' dropout. In this regard the respondents did not show much dissatisfaction regarding the accessibility and convenience of the MFI location from their work place or residence.

MFIs' service to the group was not found very negative. The respondents did not strongly agree that the loan officers rarely come to inspect the business, not open to suggestions, do not provide any advice on how to run my business, and do not behave professionally. Due to various factors, including clients not understanding the risks of borrowing and loan officers' impatience under stress can generate bad interaction/harsh behavior with clients and ultimate discontinuation. The psycho-social program of MFIs help field officers and clients to deal with stress is showing positive results and is helping in building long-term relationships. 
Environmental reasons behind client dropouts mainly consider family or personal reasons that can stop a member taking loan from an MFI. The responses show that clients disinterest to take another loan is the most important cause of dropout followed by clients' solvency, employment opportunity or leading a profitable micro enterprise and insufficient loan amount. This shows, that major reason for dropping out is not related to the organization but to the fact that clients become independent as their business starts to give profits and no longer need any loan. Other least significant MFI loan dropout causes include: migration to another location, unexpected happening, e.g., death, illness, etc., misuse of loan to meet household expenses, ineligibility for loan and family or relatives unwillingness. The minimal dropout due to family disapproval indicates that there is a cultural shift in norms and husbands and other family members, are more comfortable with seeing their female members actively participate in income generating activities.

\subsection{Recommendations}

Based on the conclusions of the study, the following recommendations are made.

1. Increase the loan ceiling so that clients who have a higher loan demand can acquire loans. The lack of a higher loan ceiling may be the key factor in retaining the clients who no longer need a loan.

2. The loan repayment procedure or the loan terms of the MFI must be improved with greater flexibility. The loan terms should be designed in such a way that meets individual clients' needs and is tailored to serve him/her the best way.

3. If MFI is to continue to demand compulsory savings then it should only require a fair minimum, pay reasonable interest on it, and, within limits, it should provide clients with flexibility in access.

4. MFIs should conduct regular market research, and attempt to meet their customer's needs in the best ways possible. The MFIs should shift from a product centric approach to a more market centric one. Taking a market centric approach to product development will ensure higher client satisfaction and warrant a sustainable finance program.

5. Employees and clients must be involved in sessions where they discuss about the values of the MFIs. When the stakeholders' values are in line with that of the MFIs, the whole system takes a more wholesome outlook and is the key to sustainable development for MFI and clients, alike. 


\section{END NOTES}

1. Microfinance: Practice of providing financial services, such as microcredit, microsavings or micro-insurance to poor people.

2. Microfinance Institution (MFI): An organization, regulated financial institution or commercial bank that provides microfinance products and services to low-income clients.

3. Dropout: All those who exit a program. In this case, a client who voluntarily decides to not take another loan after repaying the previous one or a client who does not take another loan for a certain number of months.

4. Microcredit: Extension of very small loans to the unemployed, to poor entrepreneurs and to others living in poverty who are not considered bankable

5. Default; The situation that occurs when a borrower cannot or will not repay his/her loan and the MFI no longer expects to receive repayment.

6. Declining Method: An interest rate that is based on the current borrowed amount with the client and not the principle amount.

7. Credit: Borrowed funds with specified repayment terms

8. Mohajons: Local rich money-lenders (Loan sharks) who offer loans to villagers at high interest rates at time of their destitute/need.

9. Face Validity implies that the items chosen to measure a variable are logically related to it.

10. Voluntary Savings: Deposits from general public and members that are not maintained as a condition for accessing a current or future loan and are held with the institution.

11. Group loan or Group-based Lending: Lending involving group formation of people with common interests or occupations or same region. 


\section{References}

Barua, P., \& Sulaiman, M. (2007). Impact Evaluation and Client Satisfaction of Northwest Microfinance Expansion Project. BRAC, Research and Evaluation Division.

CHIP (2002). Civil Society Human and Institutional Development Programme). The Causes of the High Rate of Drop-out amongst Micro-finance Borrowers. EU-Desk Research Report.

Cull, R., Demirguc-Kunt, A., \& Morduch, J. (2009). Microfinance Tradeoffs: Regulation, Competition, and Financing. Policy Research Working Paper, The World Bank, Development Research Group: Finance and Private Sector Team .

GDE (2013). General Division of Economics. Millenium Development Goals Bangladesh Progress Report. Dhaka: Planning Comission, Government of Bangladesh.

Hossain, A. (2003). Cause and Effect Analysis of Membership Discontinuation: A Case Study. BRAC, Research and Evaluation, Division, Dhaka.

Karim, M. R. (2005). What Causes Dropout from Microcredit Programmes? Pakistan Journal of Social Sciences , 3 (9).

Khalily, M. B., \& Faruqee, R. (2011). Multiple Borrowing by MFI Clients. Dhaka: Institute of Microfinance.

Khalily, M. B., Khaleque, M. A., \& Badruddoza, S. (2014). Impact of Regulation on the Cost Efficiency of Microfinance Instituitions in Bangladesh. Dhaka: Institute of Microfinance \& Microcredit Regulatory Authority.

Khandker, S. R., \& Samad, H. A. (2013). Microfinance Growth and Poverty Reduction in Bangladesh: What Does the Longitudinal Data Say? Working Paper No. 16. Institute of Microfinance.

Khandker, S. R., Khalily, M. B., \& Samad, H. A. (2010). Seasonality and Hard-Core Poor with Microfinance. Dhaka: Institute of Microfinance.

Majumder, Dilip (2009). Member Dropouts of SAJIDA Foundation Microfinance Program. Dhaka: SAJIDA Foundation.

Pagura, M. E. (2003). Examining Client Exit in Microfinance: Theoretical and Empirical Perspectives. Dissertation, Ohio State University.

Pearlman, S. (2014). Dropouts, Defaulters and Continuing Borrowers: Client Exit from Microfinance. Vassar College, Department of Economics.

Quayes, S., \& Khalily, M. B. (2013). Effiiciency of Microfinance Institutions. Dhaka: Institute of Microfinance.

Rahman, S. (2006). Client Satisfaction In Microfinance Program. CARE Bangladesh.

Rani, I., Jalbani, A. A., \& Laghari, M. K. (2012). Exploratory Research on the Experiences of Dropout Customers of Microfinance Bank in Pakistan. Interdisciplinary Journal of Contemporary Research in Business , 3 (9).

$34 \sim$ Nepalese Journal of Insurance and Social Security 
Simanowitz, A. (2000). Client Exit Surveys: A Tool for Understanding Client Drop-Out. Journal of Microfinance , 2 (1).

Wright, G. A. (1997). Drop-outs and Graduates - Lessons from Bangladesh. MicroSave Market-led solutions for financial services. . (2000). Dropouts and Graduates: What Do They Mean for MFIs?

Zaman, M. (2013). Achievement and Problems of Microfinance of Two Leading MFIs in Bangladesh: A Case Study of GB and ASA. ASA University Review , 7 (2). 


\section{Appendix 1}

\section{Coordination Schema with Mean Indices- Causes of dropout}

\begin{tabular}{|c|c|c|}
\hline Complex Variables & & Simple Variables \\
\hline Organizational & 1) & Increment in loan size was inadequate (1.50) \\
\hline \multirow{14}{*}{$\begin{array}{l}\text { (Product features) } \\
(1.61)\end{array}$} & 2) & Waiting time to receive loan was very long (1.47) \\
\hline & 3) & Loan application fee was excessive (1.40) \\
\hline & 4) & Loan application system was not user-friendly (1.37) \\
\hline & 5) & Range of loan packages was narrow (1.17) \\
\hline & 6) & Installment size was not negotiable (2.53) \\
\hline & 7) & Repayment intervals were short (2.40) \\
\hline & 8) & There was no grace period (1.97) \\
\hline & 9) & Interest rate was high (1.93) \\
\hline & 10) & The system of paying overdue was strict (1.64) \\
\hline & 11) & Savings requirement for borrowing was high (1.67) \\
\hline & 12) & There was no interest on voluntary savings (1.37) \\
\hline & 13) & Terms of savings withdrawal was inflexible (1.33) \\
\hline & 14) & Rate of voluntary savings was high (1.30) \\
\hline & 15) & The savings scheme of the MFI was not beneficial (1.07) \\
\hline \multirow{16}{*}{$\begin{array}{l}\text { Clientele (Peer/Group/ } \\
\text { Co-operative) (1.25) }\end{array}$} & 16) & Alternative loans were available at that time (1.43) \\
\hline & 17) & Maximum loan size was inadequate (1.33) \\
\hline & 18) & The business was not making profit (1.30) \\
\hline & 19) & $\begin{array}{l}\text { The interest amount paid to the MFI was higher than the } \\
\text { profit I make (1.23) }\end{array}$ \\
\hline & 20) & The loan from MFI is more expensive than other MFIs (1.17) \\
\hline & 21) & $\begin{array}{l}\text { The loan amount does not vary according to my business re- } \\
\text { quirements (1.13) }\end{array}$ \\
\hline & 22) & $\begin{array}{l}\text { The MFI loan is more expensive than traditional money lend- } \\
\text { ers (1.07) }\end{array}$ \\
\hline & 23) & The group meetings were long (1.37) \\
\hline & 24) & My group members were unfriendly (1.20) \\
\hline & 25) & I disliked the peer guarantee system (1.17) \\
\hline & 26) & The MFI is located very far from my workplace (1.27) \\
\hline & 27) & The MFI is located very far from my residence (1.20) \\
\hline & 28) & The loan officers rarely come to inspect my business (1.40) \\
\hline & 29) & Officers were not open to suggestions (1.30) \\
\hline & 30) & $\begin{array}{l}\text { The MFI officials do not provide any advice on how to run my } \\
\text { business (1.23) }\end{array}$ \\
\hline & 31) & Loan officers did not behave professionally (1.20) \\
\hline
\end{tabular}


Environmental

(Personal/ Family) (1.62)
32) I was not interested to take another loan at that time (3.17)

33) I became solvent enough (1.93)

34) I found employment/or leading a profitable micro enterprise (1.57)

35) I needed a loan larger than what my MFI could provide (1.57)

36) I have not benefited from the microfinance loan (1.27)

37) I used the loaned money to meet household expenses (1.34)

38) I became legally ineligible for loan (1.30)

39) I migrated to another location (1.47)

40) Some unexpected events took place (death, illness, etc.) (1.47)

41) My family or relatives were against the loan (1.13) 
Appendix 2

Causes of Dropouts

\begin{tabular}{|c|c|c|c|}
\hline Sl. No. & Causes of Dropout & Mean & St. Dev. \\
\hline 1 & Not interested to take another loan at that time & 3.17 & 2.001 \\
\hline 2 & Instalment size was not negotiable & 2.53 & 1.408 \\
\hline 3 & Repayment intervals were short & 2.40 & 1.163 \\
\hline 4 & There was no grace period & 1.97 & 1.474 \\
\hline 5 & Interest rate was high & 1.93 & 1.258 \\
\hline 6 & I became solvent enough & 1.93 & 1.552 \\
\hline 7 & Savings requirement for borrowing was high & 1.67 & 0.994 \\
\hline 8 & The system of paying overdue was strict & 1.64 & 1.096 \\
\hline 9 & I needed a loan larger than what my MFI could provide & 1.57 & 1.251 \\
\hline 10 & $\begin{array}{l}\text { I found employment/ or leading a profitable micro enter- } \\
\text { prise }\end{array}$ & 1.57 & 1.194 \\
\hline 11 & Increment in loan size was inadequate & 1.50 & 0.777 \\
\hline 12 & Waiting time to receive loan was very long & 1.47 & 0.900 \\
\hline 13 & Some unexpected events took place (death, illness etc.) & 1.47 & 1.167 \\
\hline 14 & I migrated to another location & 1.47 & 1.224 \\
\hline 15 & Alternative loans were available at that time & 1.43 & 1.073 \\
\hline 16 & Loan application fee was excessive & 1.40 & 0.724 \\
\hline 17 & The loan officers rarely come to inspect my business & 1.40 & 0.770 \\
\hline 18 & Loan application system was not user-friendly & 1.37 & 0.765 \\
\hline 19 & There was no interest on voluntary savings & 1.37 & 0.850 \\
\hline 20 & The group meetings were long & 1.37 & 0.718 \\
\hline 21 & I used the loaned money to meet household expenses & 1.34 & 0.974 \\
\hline 22 & Maximum loan size was inadequate & 1.33 & 0.844 \\
\hline 23 & Terms of savings withdrawal was inflexible & 1.33 & 0.547 \\
\hline 24 & Rate of voluntary savings was high & 1.30 & 0.702 \\
\hline 25 & Officers were not open to suggestions & 1.30 & 0.535 \\
\hline 26 & The business was not making profit & 1.30 & 0.915 \\
\hline 27 & I became legally ineligible for loan & 1.30 & 1.022 \\
\hline 28 & The MFI is located very far from my workplace & 1.27 & 0.907 \\
\hline 29 & I have not benefited from the microfinance loan & 1.27 & 0.691 \\
\hline 30 & $\begin{array}{l}\text { The amount of interest paid to the MFI was higher than } \\
\text { the profit I remain with }\end{array}$ & 1.23 & 0.774 \\
\hline 31 & $\begin{array}{l}\text { The MFI officials do not provide any advice on how to run } \\
\text { my business }\end{array}$ & 1.23 & 0.504 \\
\hline 32 & My group members were unfriendly & 1.20 & 0.484 \\
\hline
\end{tabular}

$38 \sim$ Nepalese Journal of Insurance and Social Security 


\begin{tabular}{|c|c|c|c|}
\hline Sl. No. & Causes of Dropout & Mean & St. Dev. \\
\hline 33 & Loan officers did not behave professionally. & 1.20 & 0.484 \\
\hline 34 & The MFI is located very far from my residence & 1.20 & 0.761 \\
\hline 35 & Range of loan packages was narrow & 1.17 & 0.379 \\
\hline 36 & I disliked the peer guarantee system & 1.17 & 0.592 \\
\hline 37 & $\begin{array}{l}\text { The loan from MFI is more expensive than other financial } \\
\text { institutions }\end{array}$ & 1.17 & 0.592 \\
\hline 38 & $\begin{array}{l}\text { The loan amount does not vary according to my business } \\
\text { requirements }\end{array}$ & 1.13 & 0.346 \\
\hline 39 & My family or relatives were against the loan & 1.13 & 0.346 \\
\hline 40 & $\begin{array}{l}\text { The loan from MFI is more expensive than traditional } \\
\text { money lenders }\end{array}$ & 1.07 & 0.254 \\
\hline 41 & The savings scheme of the MFI was not beneficial & 1.07 & 0.254 \\
\hline
\end{tabular}

